\title{
Pemanfaatan Teknologi Media Pembelajaran di Masa Pandemi Covid-19
}

\author{
Unik Hanifah Salsabila ${ }^{1}$, Windi Mega Lestari ${ }^{2}$, Riasatul Habibah ${ }^{3}$, Oqy \\ Andaresta $^{4}$, Diah Yulianingsih ${ }^{5}$ \\ 1,2,3,4,5. Universitas Ahmad Dahlan \\ Email: unik.salsabila@pai.uad.ac.id ${ }^{1}$, windi1800031145@webmail.uad.ac.id ${ }^{2}$, \\ riasatulhabibah14@ gmail.com ${ }^{3}$, oqy180003125@webmail.uad.ac.id ${ }^{4}$, \\ diah1811031246@webmail.uad.ac.id
}

\begin{abstract}
This study aims to determine the use of online learning technology during the Covid-19 virus pandemic which has spread throughout the world, especially Indonesia using the google classroom, YouTube, WAG, Edmodo, Zoom, and Googlemeet platforms. The research we conducted used a qualitative approach by collecting data with several methods that we did in writing this article. We use the interview method, literature study and literature, then the results show that technology has many roles and benefits in the world of education, especially during distance learning in the midst of the Covid-19 pandemic. By conducting interviews with teachers and students, it can be concluded that the learning media technology that is widely used by elementary schools is WAG and also google classroom.
\end{abstract}

Keywords: Covid-19, google classroom, platform, online learning, WAG.

\begin{abstract}
Abstrak
Penelitian ini bertujuan untuk mengetahui pemanfaatan teknologi pembelajaran daring saat pandemi virus Covid-19 yang telah menyebar di seluruh dunia terutama Indonesia menggunakan platform google classroom, YouTube, WAG, Edmodo, Zoom, serta Googlemeet. Penelitian yang kami lakukan ini menggunakan pendekatan kualitatif dengan cara mengumpulkan data dengan beberapa metode yang kami lakukan dalam penulisan artikel ini. Kami menggunakan metode wawancara, studi pustaka dan literatur, kemudian hasilnya menunjukkan bahwa teknologi memiliki banyak sekali peran dan manfaatnya dalam dunia pendidikan terlebih saat pembelajaran jarak jauh di tengah pandemi Covid-19 ini. Dengan melakukan wawancara kepada guru dan peserta didik, dapat disimpulkan bahwa teknologi media pembelajaran yang banyak di gunakan oleh Sekolah Dasar adalah WAG dan juga google classroom.
\end{abstract}

Kata Kunci: Covid-19, google classroom, platform, pembelajaran daring, WAG. 


\section{PENDAHULUAN}

Saat pandemi Covid-19 menyebar diseluruh belahan dunia termasuk di Indonesia, seluruh aktivitas yang kita lakukan menjadi terbatasi demi mencegah penyebaran viru s corona yang ada di setiap negara terutama Indonesia. Pemerintah melakukan segala cara agar penyebaran virus corona bisa segera teratasi dan tidak semakin banyak korban yang terkena akan virus tersebut, kerena virus ini tergolong virus yang berbahaya dan dapat menular dari manusia satu ke manusia yang lainnya. Dengan demikian, pemerintah membuat beberapa kebijakan yang harus dipatuhi oleh masyarakat dengan langkah pertama yaitu melakukan lockdown dan kita dihimbau juga agar melakukan physical quarantine untuk daerah yang memang sudah termasuk kedalam zona berbahaya atau zona merah. Untuk mengurangi resiko terkena penularan virus Covid-19, salah satunya dengan cara menjaga jarak atau physical distancing.

Karena menjaga jarak antara satu orang dengan yang lainnya dan menghindari perkumpulan atau tempat ramai juga merupakan salah satu upaya untuk mengurangi resiko tertular virus Covid-19, pemerintah akhirnya menetapkan untuk memberlakukan bekerja dan belajar dari rumah. Dengan demikian, setiap sektor yang ada menjalani setiap aktivitas pekerjaan maupun pembelajaran dari rumah termasuk sektor pendidikan. Pendidikan identik dengan sekolah, dalam keaadaan dan kondisi yang seperti sekarang ini, proses belajar dan mengajar harus tetap berjalan seperti hari-hari biasa. Dengan begitu, pembelajaran tidak akan tertinggal. Hanya saja pembelajaran di tengah pandemi seperti ini tidak secara langsung atau bertatap muka, melainkan Kementrian Pendidikan telah mengeluarkan kebijakan dengan mengubah sistem pembelajaran tatap muka menjadi pembelajaran daring (dalam jaringan/ online), hingga ada surat edaran yang dikeluarkan oleh Kementrian Pendidikan dan Kebudayaan (Kemendikbud) Direktorat Pendidikan Tinggi No.1 Tahun 2020.

Kebijakan yang dikeluarkan tersebut membuat pembelajaran yang dilakukan disekolah maupun perguruan tinggi yang ada di Indonesia harus dilakukan secara daring untuk menyikapi pandemi Covid-19 yang mana telah terjadi di seluruh dunia. Dengan pembelajaran yang dilakukan secara daring tentu memiliki dampak tersendiri, sebab pembelajaran yang biasanya dilakukan secara bertatap muka didalam ruangan dengan dilengkapi fasilitas-fasilitas yang ada sekarang harus dilakukan dengan jarak dan melalui media teknologi pembelajaran komunikasi dan informasi.

Dengan perkembangan teknologi yang semakin maju, sehingga berdampak pula pada kemajuan media pembelajaran yang digunakan sekarang ini meskipun dengan penanaman yang berbedabeda (Yaumi, 2018). Teknologi dan 
informasi tersebut menjadi solusi untuk pembelajaran yang dilakukan sekarang ini. Media pembelajaran telah maju dan berkembang seiring dengan lahirnya revolusi komunikasi yang dimanfaatkan untuk tujuan pembelajaran selain media yang sudah ada sebelumnya seperti guru, buku teks dan papan tulis (Yaumi, 2018), tetapi teknologi pemebelajaran disini dapat berupa media yang bisa membantu untuk mempermudah manusia dalam hal pekerjaan terutama dalam bidang pendidikan apalagi ketika dimasa pandemi yang sekarang sedang kita rasakan.

Banyak sekali teknologi media pembelajaran yang berbentuk platform yang digunakan disetiap instansi pendidikan, pada tingkat sekolah maupun di perguruan tinggi untuk mengefektifkan proses pembelajaran yang dilakukan. Seperti Google Classroom, E-learning, YouTube, WAG, Edmodo, Zoom, Googlemeet dan platform lainnya yang mampu menjadi penunjang fasilitas belajar dari rumah. Media pembelajaran disebut juga sebagai alat atau sumber belajar yang dapat membantu seorang guru dalam menyampaikan pesan kepada siswa (Yunanta, 2019). Setiap platform yang digunakan tentu memiliki kekurangan serta kelebihan yang dimiliki pada saat digunakan untuk proses pembelajaran.

\section{KAJIAN TEORI}

\section{Covid-19}

Corona virus merupakan keluarga besar virus yang menyebabkan penyakit mulai dari gejala ringan sampai berat. Tanda serta gejala umum dari corona virus ialah pada gangguan pernafasan seperti demam, batuk serta sesak nafas. (Islabiah, 2020). Terdapat dua jenis coronavirus yang diketahui menyebabkan penyakit yang dapat menimbulkan gejala berat yang dapat menyerang saluran pernafasan, seperti Middle East Respiratory Syndrome (MERS) dan Severe Acute Respiratory Syndrome (SARS) (Dewi, 2020).

Corona Virus juga mampu berujung pada meninggal dunia yang mana kasus yang meninggal setiap hari kian bertambah dan selalu mengalami kenaikan orang-orang yang terkena corona virus tersebut. Diawal tahun 2020, di seluruh dunia bahkan di negara kita sendiri dihebohkan dengan menyebarnya virus baru yaitu Corona Virus. Jenis baru (SARS-CoV-2) dan penyakitnya disebut Coronavirus Disease 2019 (COVID-19). Corona merupakan virus RNA strain tunggal positif berkapsul dan tidak bersegmen. Corona Virus bersifat sensitif terhadap panas dan secara efektif dapat dinaktifkan oleh desinfektan mengandung klorin, pelarut lipid dengan suhu $56^{\circ} \mathrm{C}$ selama 30 menit, eter, alkohol, detergen non-ionik, dan kloroform. Klorheksidin tidak efektif dalam me-nonaktifkan virus (Korsman, 2012)

$$
\text { Indikasi }
$$

Penyebaran

Coronavirus diketahui melalui droplet dan kontak dengan droplet. Prognosis pasien sesuai derajat 
penyakit, derajat ringan berupa infeksi saluran nafas atas umumnya prognosis baik tetapi bila terdapat Acute Respiratory Distress Syndrome (ARDS) prognosis menjadi buruk terutama bila disertai komorbid usia lanjut dan mempunyai riwayat penyakit paru sebelumnya. Pencegahan utama sekaligus tata laksana adalah isolasi kasus untuk pengendalian penyebaran (Diah, 2020).

Informasi tentang virus ini tentunya masih sangat terbatas karena banyak hal masih dalam penelitian dan data epidemiologi akan sangat berkembang juga untuk itu tinjauan ini merupakan tinjauan berdasarkan informasi terbatas yang dirangkum dengan tujuan untuk memberi informasi dan sangat mungkin akan terdapat perubahan kebijakan dan hal terkait lainnya sesuai perkembangan hasil penelitian, data epidemiologi dan kemajuan diagnosis dan terapi.

\section{Pembelajaran Daring}

Adanya virus yang muncul secara tiba-tiba yang menyerang hampir diseluruh dunia termasuk Indonesia membuat setiap aktivitas manusia baik ekonomi, sosial bahkan pendidikan juga mengalami dampak yang sangat signifikan. Didalam pendidikan, semua pembelajaran dilakukan secara daring/ online. Pembelajaran daring merupakan sistem pembelajaran yang dilakukan dengan menggunakan perangkat pedagogi atau alat bantu pendidikan yang memungkinkan harus menggunakan akses internet dan teknologi informasi yang baik untuk menjadi fasilitas dalam pembentukan proses belajar dan pengetahuan melalui interaksi yang dilakukan (Roida, 2020).

\section{Google Classroom}

Google Classroom merupakan sebuah aplikasi yang digunakan dalam dunia pada lingkup pendidikan yang mampu mempermudah didalam sebuah pembelajaran yang sedang berlangsung terutama pada saat masa pandemi seperti sekarang ini (Roida, 2020). Google Classroom digunakan oleh setiap orang dari ruang lingkup/ jenjang pendidikan yang berbedabeda baik dari tingkat SD, SMP, SMA/SMK maupun Perguruan Tinggi. Disamping mudah didalam menggunakannya Google Classroom juga sangat efisien dan tidak terlalu rumit pada saat kita akan mengakses dan menggunakannya untuk melakukan pembelajaran yang diberikan oleh guru maupun dosen yang menggunakan platform ini didalam proses pembelajaran jarak jauh dimasa pandemi ini.

Gmail, Youtube, Google Drive, Google Maps, dan Google Translate merupakan fitur-fitur pendukung yang ada pada platform google classroom. Di antara fitur yang dimiliki oleh google classroom adalah assignments (tugas), grading (pengukuran), communication (komunikasi), time-cost (hemat waktu), archieve course (arsip program), kode kelas tampilan, mobile application (aplikasi seluler), 
dan privacy (keamanan pribadi) (Islami, 2020).

\section{E-learning}

E-learning merupakan salah satu bentuk media atau platform pembelajaran yang didukung dengan pemanfaatan teknolgi informasi dan komunikasi. Serta bisa digunakan untuk penunjang pembelajaran daring seperti sekarang ini (Hanum, 2013).

$$
\text { E-learning merupakan }
$$

salahsatu platform yang digunakan untuk menunjang berjalannya suatu pendidikan dari berbagai jenjang baik dari SD, SMP, SMA, maupun Perguruan Tinggi. Akan tetapi perlu kita ketahui juga bahwasanya $e$ learning masih terbilang sangat baru sehingga perkembangan definisi dan implementasi dari sistem e-learning ini masih beragam dan masih belum mempunyai standar yang pokok. Dengan adanya e-learning tentu pembelajaran menjadi lebih efektif dan fleksibel bisa di akses dimana saja dan kapan saja asalkan ada paket internet yang mampu menjadi penunjang.

Karena belum ada standar definisi dan implementasi yang baku dari e learning sehingga memiliki definisi yang bervariasi, adapun yang mengatakan bahwa E-learning kependekan dari electronic learning (Sohn, 2005). Definisi e-learning menurut The ILRT of Bristol University (2005) e-learning sebagai penggunaan teknologi elektronik untuk mengirim, mendukung, dan meningkatkan pembelajaran, dan penilaian pada saat proses pembelajaran berlangsung.

Dari beberapa definisi
tersebut, dapat kita ketahui
bahwasanya dengan adanya $e$ learning sebagai sarana untuk mempermudah dalam mengakses pembelajaran, karena memang ciri dari pembelajaran menggunakan platform e-learning adalah terciptanya lingkungan belajar yang flexibel dan distributed (Suartama, 2014). Dikatakan flexibel karena pembelajaran dengan e-learning dapat diakses dimanapun kita berada dan kapan saja, tetapi perlu kita ketahui semua bahwasannya pembelajaran dengan menggunakan e-learning ini memerlukan sinyal internet atau hanya dapat dilakukan dengan sistem dalam jaringan yang mampu menjadi pendukung.

\section{WhatsApp}

WhatsApp merupakan salah satu media komunikasi yang sudah tidak asing lagi ditelinga kita bahkan sangat populer sekali serta merupakan platform yang kita gunakan saat ini baik untuk kepentingan pribadi maupun sosial. Aplikasi yang satu ini, hampir dimiliki oleh semua pengguna gadget. Selain dapat digunakan untuk berkomunikasi dengan jarak jauh, platform ini juga bisa digunakan sebagai media penunjang pada proses pembelajaran seperti pada masa pandemi seperti sekarang ini. Platform ini merupakan alat yang digunakan untuk melakukan komunikasi jarak jauh berupa 
percakapan baik menggunakan tulisan, gambar, suara maupun video.

WhatsApp mampu terhubung dengan teman serta keluarga kita yang ada dimanapun dan kapanpun ketika kita memiliki jaringan yang baik yang mampu menjadi pendukung untuk kita mengaksesnya (Roida, 2020).

\section{Zoom}

Zoom adalah aplikasi pertemuan dengan video dan berbagi layar dengan jumlah peserta hingga 100 anggota bahkan sampai 1000 lebih yang dapat bergabung di dalam aplikasi ini. Aplikasi video conference ini memiliki durasi waktu saat kita melakukan meeting dengan yang orang lain. Meskipun demikian, aplikasi ini sangat membantu untuk mereka yang ingin melakukan diskusi secara langsung menggunakan ruang virtual karena memiliki kapasitas ruang yang cukup besar dalam sekali pertemuan.

Zoom merupakan aplikasi komunikasi dengan menggunakan video sehingga pada saat digunakan untuk proses pembelajaran maka kita akan merasa bahwa kita sedang tatap muka secara langsung karena kita mampu melihat orang yang jauh dengan menyalakan camera yang kita miliki didalam menggunakan platform zoom ini (Astini, 2020).

\section{METODE PENELITIAN}

Artikel ini dibuat dengan menggunakan penelitian literatur, studi pustaka serta wawancara. Penelitian literatur ialah penelitan yang pengumpulan datanya mengambil data dari pustaka, membaca, mencatat dan mengumpulkan informasi. Penelitian studi pustaka merupakan suatu penelitian yang digunakan dengan cara mengumpulkan informasi dan data dengan bantuan berbagai macam material yang ada diperpustakaan seperti dokumen, buku, majalah, berita dan sebagainya. Menurut ahli penelitian kepustakaan merupakan kajian teoritis, referensi serta literatur ilmiah lainnya yang berkaitan dengan budaya, nilai dan norma yang berkembang pada situasi sosial yang diteliti (Sugiyono, 2012). Dalam penelitian ini pengumpulan data dilakukan dengan cara memperoleh dari artikel-artikel, jurnal online, buku digital serta wawancara kepada beberapa pihak seperti peserta didik dan guru.

\section{HASIL DAN PEMBAHASAN}

Pembelajaran yang dilakukan dengan memanfaatkan teknologi informasi dan komunikasi tergantung pada peran pengajar sebagai fasilitastor bukan hanya sebagai pemberi informasi saja, tetapi juga memberikan kemudahan dalam pembelajaran (Hanum, 2013). Dalam proses belajar dan mengajar yang dilakukan dengan memanfaatkan dan menggunakan teknologi informasi dan komunikasi ini merupakan salah satu bimbingan dari pengajar untuk senantiasa memfasilitasi pembelajaran yang efektif bagi pembelajar didalam melakukan 
pembelajaran dimasa pandemi Covid19 (Munir, 2009).

Didalam pembelajaran jarak jauh yang kita laksanakan sekarang tidak dapat dipungkiri bahwasannya saat menggunakan teknologi informasi komunikasi yang ada baik guru maupun murid masih sangat rendah didalam pengusaan teknologi yang ada. Teknologi sekarang hidup secara berdamping dengan kita namun tidak semua orang mampu menggunakan teknologi yang ada dengan maksimal dan mampu memahami setiap manfaat dan fungsi dari teknologi yang digunakan tersebut dengan baik. Kepemilikan perangkat pendukung teknologi juga menjadi masalah tersendiri yang kita alami pada saat masa pembelajaran jarak jauh ini. Masih terdapat guruguru maupun siswa yang tidak memiliki perangkat teknologi sebagai fasilitas penunjang dari kegiatan belajar mengajar pada sistem daring, seperti halnya laptop dan gadget. Jikapun mereka memiliki fasilitas pendukung tersebut namun terkadang laptop maupun gadget yang mereka miliki itu kurang memadai untuk digunakan dalam melakukan kegiatan pembelajaran yang dilaksanakan (Aprilia, 2020).

Permasalahan yang muncul tidak hanya berasal dari siswa, namun juga dari guru, orang tua, maupun pihak-pihak yang terlibat dalam dunia pendidikan. Misalnya materi mata pelajaran yang belum selesai disampaikan kepada siswa kemudian guru mengganti dengan tugas yang lainnya (Argubi, 2020). Pada saat pembelajaran online dilaksanakan banyak siswa mengeluhkan karena banyaknya tugas yang diberikan oleh guru kepada murid selama penerapan pembelajaran dari rumah yang sedang berlangsung dari bulan Maret 2020 hingga saat ini. Masalah lainnya yang muncul yaitu akses informasi yang kadang terbatas dan terhambat oleh jaringan yang mengakibatkan keterlambatan saat mencari informasi pada saat proses pembelajaran sedang berlangsung. Pada penerapan pembelajaran online saat ini, masih banyak siswa yang kesulitan akses internet, hal tersebut menjadi penghambat siswa dalam mengikuti proses pembelajaran maupun mengumpulkan tugas yang diberikan oleh guru.

Pandemi yang sedang berlangsung ini menyebabkan sektor perekonomian yang tidak seimbang ini berdampak pada proses pembelajaran yang dilakukan karena baik orang tua maupun guru pasti harus mengeluarkan dana untuk menambah pengeluaran untuk membeli kuota atau internet untuk tetap berjalannya proses pembelajaran yang dilakukan dimasa pandemi seperti sekarang ini, tetapi Kemendikbud akhirnya memberikan bantuan berupa subsidi kuota internet yang diberikan kepada guru, dosen, peserta didik dan mahasiswa, dengan tujuan supaya meringankan pengeluaran biaya untuk kuota yang mahal yang dikeluarkan baik oleh pendidik (guru dan dosen) maupun peserta didik (siswa maupun mahasiswa). Guru juga mengalami 
kesulitan dalam mengoreksi dan memeriksa setiap PR (Pekerjaan Rumah) yang diberikan kepada peserta didik, juga menyebabkan kapasitas ruang penyimpanan ponsel semakin terus berkurang karena banyaknya file yang harus diunduh didalam proses pembelajaran yang berlangsung sekarang ini. Penerapan pembelajaran sistem daring juga membuat guru berpikir ulang terhadap model dan metode pembelajaran yang akan digunakan didalam proses pembelajaran jarak jauh seperti saat ini. Ketidaksiapan stakeholder sekolah dalam melaksanakan pembelajaran daring menjadi faktor utama masalah dan hambatan tersebut.

Namun pembelajaran yang dilakukan dari rumah oleh setiap peserta didik, memudahkan orang tua dalam memantau atau mengawasi secara langsung tentang perkembangan belajar anak yang mungkin pada saat sebelum pandemi ini kurang didalam memberi pengawasan atau monitoring terhadap anak. Terlebih untuk anak-anak yang masih duduk di bangku Sekolah Dasar, mereka masih ada yang menganggap bahwa belajar di rumah sama dengan libur karena mereka tidak datang ke sekolah seperti biasanya. Dengan demikian, anakanak sangat memerlukan edukasi dari kedua orang tuanya tentang apa yang sedang terjadi saat ini. Orang tua mempunyai tugas dan peran untuk membimbing anak supaya dapat mengikuti pembelajaran yang dilakukan secara daring ini dengan baik supaya tidak hanya bermain karena mereka tidak datang ke sekolah. Komunikasi yang intensif dibutuhkan baik antara guru dengan siswa, siswa dengan orang tua, maupun guru dengan orang tua untuk selalu sejalan dalam membimbing kegiatan belajar siswa di rumah.

Banyak sekali model pembelajaran yang dilakukan didalam masa pandemi seperti sekarang ini. Berbagai platform juga digunakan didalam pembelajaran jarak jauh ini yang digunakan sebagai penunjang didalam proses kegiatan belajar mengajar seperti google classroom, elearning, edmodo, zoom, google meet, whatsApp dan lain sebagainya yang mampu menjadi penunjang agar proses pembelajaran yang dilakukan mampu berjalan dengan baik meski dimasa pandemi seperti sekarang ini. Karena pandemi ini, pembelajaran jadi tidak efektif, terutama untuk peserta didik yang masih duduk di bangku Sekolah Dasar. Karena pada dasarnya mereka belum banyak yang mengenal dengan platform pembelajaran untuk penunjang pembelajarannya yang dilakukan dirumah, dengan itu mereka harus didampingi oleh kedua orang tuanya pada saat proses belajar berlangsung. Tetapi, ada beberapa platform yang cenderung ringan dan mudah saat digunakan, salah satunya adalah $W A G$ dan google classroom.

Berdasarkan hasil wawancara, sebagian besar peserta didik di Sekolah Dasar menggunakan teknologi media pembelajaran dengan platfoorm WAG dan juga google 
classroom, dengan alasan karena keduanya sangat mudah digunakan. Fungsi kedua platform tersebut tidak jauh berbeda, sama-sama bisa digunakan untuk mengirim gambar, video, dokumen dan lain sebagainya. Platform ini juga memudahkan guru dalam memberikan materi kepada peserta didik khususnya yang ada di Sekolah Dasar untuk menyampaikan pembelajaran supaya bisa dengan mudah di mengerti oleh peserta didik. Dalam hal penyampaian materi, guru juga harus bisa mengemas materi yang akan disampaikan dengan sekreatif mungkin, khususnya untuk peserta didik Sekolah Dasar supaya mereka tidak merasa bosan. Jadi meskipun anak-anak saat ini belajar di rumah masing-masing, mereka tetap merasa bahwa belajar di rumah juga menyenangkan dan menarik sehingga tidak membosankan dan mampu menambah semangat siswa didalam proses belajar yang dilakukan dari rumah masing-masing menggunakan asilitas penunjang yang telah disediakan secara pribadi tersebut.

Untuk membuat video pembelajaran dan materi supaya lebih menarik, guru dapat menggunakan aplikasi-aplikasi penunjang yang mudah digunakan. Setelah itu, materi atau video pembelajaran yang sudah dibuat dapat disampaikan oleh guru kepada peserta didik melalui platform seperti WAG dan google classroom seperti yang disebutkan di pembahasan sebelumnya.

Di masa pandemi seperti sekarang ini, belajar dari rumah atau belajar secara jarak jauh menjadi jalan utama agar pembelajaran tetap berlangsung dengan baik dan efektif. Akan tetapi pembelajaran dilaksanakan dengan cara online atau daring dengan menggunakan teknologi sekarang yang semakin canggih yang dapat digunakan untuk menunjang proses pembelajaran dimasa pandemi sekarang ini. Dalam hal ini, jaringan internet menjadi hal yang paling penting dalam proses pembelajaran yang dilakukan karena tanpa adanya jaringan internet peserta didik tidak dapat mengakses platform tersebut untuk melakukan pembelajaran. Dengan belum meratanya jaringan internet di Indonesia, tentu menjadi hambatan tersendiri bagi sebagian kalangan mereka yang tempat tinggalnya di daerah sulit jaringan dan yang berada dipelosok desa.

Tidak semua sekolah di Indonesia sudah mengenal platform yang dapat digunakan untuk proses pembelajaran, namun adanya pandemi ini platform pembelajaran tersebut sudah tidak asing karena semakin banyak instansi pendidikan yang menggunakannya untuk proses pembelajaran jarak jauh ini. Seperti yang penulis ketahui di daerah penulis sendiri pembelajaran untuk anak SD itu menggunakan WAG, untuk anak SMP juga menggunakan $W A G$, dan untuk anak SMA dan SMK dengan platform zoom cloud dan Moodle LMS, dan dapat disimpulkan bahwa yang paling banyak digunakan adalah WAG karena platform ini sudah sering digunakan hampir oleh 
semua pengguna gadget. Hal ini menjadi pengalaman baru bagi mereka untuk lebih dekat dengan teknologi, dan mereka mampu menggunakan teknologi tersebut dan dapat mengembangkan pengetahuan tentang cara menggunakan dan fungsi dari teknologi media pembelajaran tersebut.

Kondisi seperti sekarang ini tentu membawa kita untuk lebih dekat dengan teknologi, karena sistem pembelajaran sekarang yang membutuhkan teknologi agar pembelajaran tetap terlaksana dengan efektif dan fleksibel sehingga pembelajaran tetap berlangsung meskipun ada berbagai kendala baik itu dari jaringan internet, gadget, atau teknologi lainnya yang kurang memadai sehingga menghambat seseorang untuk mengakses pembelajaran secara daring tersebut.

Saat membahas tentang keefektifan penggunaan teknologi untuk pembelajaran di masa pandemi Covid-19 saat ini, tentu ada beberapa faktor yang mampu menunjang hal tersebut. Briliannur (2020) menjelaskan bahwa persiapan sebelum memberikan layanan belajar merupakan salah satu faktor penentu dalam keberhasilan belajar, terutama pada online learning di mana adanya jarak antara pembelajar dan pengajar. Ini menjadi perhatian dan gaya baru yang dilaksanakan dalam proses pembelajaran saat ini. Efektivitas pembelajaran dengan sistem daring tersusun dari faktor pendidik atau guru dan peserta didik, dimana guru memberikan pengajaran kepada peserta didik dan peserta didik juga menempatkan posisi sebagai mana mestinya menjadi seorang murid.

Dengan banyaknya platform pembelajaran yang tersedia, setiap pendidik pasti menggunakan platform yang berbeda-beda sesuai dengan kebutuhan dari setiap peserta didiknya itu sendiri. Seperti halnya pembelajaran yang menggunakan Google Classroom yang digunakan diberbagai kalangan karena memang google classroom itu sangat mudah digunakan dibanding platform lain dan mampu diterima disetiap kalangan baik siswa, mahasiswa, gurumaupun dosen. Selain google classroom, masih banyak platform sebagai penunjang pendidikan, ada $e$ learning yang lebih dulu dikenal dan juga digunakan dalam proses belajar dan mengajar sebelum pandemi Covid-19 ada, yaitu dengan sistem pembelajaran blended atau campuran yang terkadang pembelajaran dilakukan dengan cara tatap muka atau langsung, kadang juga dilakukan dari rumah dengan kata lain tidak bertatap muka seara langsung. Namun disetiap platform yang digunakan tentu memiliki kendala yang berbedabeda begitupun dengan google classroom. Namun disamping itu, adanya teknologi media pembelajaran tersebut tentu sangat memudahkan kita didalam menjalankan berbagai macam pelajaran dimasa pandemi Covid-19 saat ini.

Merasakan

proses pembelajaran secara daring tentu menimbulkan berbagai argumentasi mengenai keberlangsungan proses 
belajar dan mengajarnya. Selain banyak terjadi perubahan keefektifan dan keaktifan belajar tentu saja hal ini sangat menuntut secara logis maupun materil dari segi kesiapan penujangnya. Belajar dari balik pandemi Covid-19 memang tidak seefektif seperti pembelajaran tatap muka pada ranah sebelumnya yang kita ketahui, kesiapan mental dengan suasana rumah agar tetap dapat menjaga fokus terhadap materi pembelajaran menjadi faktor internal yang harus dimanage secara optimal oleh setiap pelajar agar proes pembelajaran yang dilakukan secaradaring ini tetap mampu mewujudkan daripada tujuan pembelajaran yang dilakukan.

Ada hal yang mampu kita jadikan sebuah pelajaran didalam dunia pendidikan di masa pandemi seperti sekarang ini. Bahwasannya kegiatan belajar mengajar yang dilakukan secara tatap muka dengan adanya guru jauh lebih efektif jika dibanding dengan pembelajaran yang kita lakukan saat pandemi ini. Hal tersebut dipaparkan oleh salah seorang pendidik sekolah menengah pertama (SMP) Eneng susanti, pada saat di mintai pendapat, Sabtu 31 Oktober 2020. Meskipun berbagai platfrom aplikasi penunjang belajar seperti Google Classrom telah banyak di gunakan serta manfaatkan oleh pendidik untuk mendukung kinerjanya dalam belajar namun hal ini masih berbanding jauh dengan kemudahan mengakses media belajar melalui WhatsApp. Jika di tinjau dari segi fleksibilitas banyak orang tua yang berperan sebagai monitor dirumah memilih kemudahan belajar melalui media yang sudah familiar ini, terutama pada kalangan pendidikan Sekolah Dasar dan Menengah pertama.

Perlu di sadari bahwa kesiapan Pendidik dan peserta didik di dalam belangsungnya proses pembelajaran daring menjadi tolak ukur keberhasilan pada proses penyampaian dan penyerapan materi pembelajaran yang ideal, mengingat perpindahan sistem belajar mengajar dari tatap muka menjadi pembelajaran secara daring (dari rumah) yang sangat mendadak beriringan dengan maraknya Pandemi Covid-19 ini menuntut setiap lapisan pelajar untuk lebih melek terhadap teknologi seperti penggunaan media pembelajaran. Menginternalkan pesan-pesan edukatif dari pendidik maupun orangtua berperan penting untuk melakukan pendampingan selama proses pembelajaran daring agar setiap konten yang disampaikan dapat tepat sasaran dan diterima dengan baik oleh pelajar.

Sifat keterbukaan dari pendidik dalam menerima berbagai saran dan masukan dari orang tua murid sangat memicu semangat belajar siswa, berbeda halnya dengan seorang pendidik yang pasif di dalam proses belajar mengajar maka jika secara berangsur akan mempengaruhi kondisi psikologis pada pelajar dalam proses berlangsungnya KBM (Kegiatan Belajar Mengajar) yang dilakukan. Oleh karena itu komunikasi harus tetap terjalin secara 
rapi baik dari pendidik, orang tua sebagai monitor belajar dari rumah dan peserta didik sebagai objek utama pembelajaran daring yang saat ini dilakukan.

\section{SIMPULAN}

Dengan adanya teknologi informasi dan komunikasi yang sekarang berkembang sangat pesat ini, mampu digunakan untuk menjadi penunjang didalam terselenggaranya proses belajar mengajar secara jarak jauh. Karena teknologi memiliki peranan yang mampu menjadikan proses belajar menjadi efektif dan mampu tetap berjalan dengan baik dimasa pandemi ini. Dengan begitu teknologi yang ada akan lebih memiliki manfaat yang luas yang tidak hanya kita gunakan sebagai hiburan semata namun juga mampu kita gunakan untuk mengakses setiap pembelajaran menggunakan platform yang ada dengan baik dan tidak gagap akan teknologi.

Semoga kedepannya teknologi informasi yang ada sekarang ini akan memiliki kebermanfaatan yang lebih bagi sektor pendidikan khususnya dan setiap pendidik harus mampu menguasai kemajuan teknologi agar proses pembelajaran yang dilakukan dengan menggunakan teknologi yang sudah dijelaskan mampu mengalami kemajuan dan mampu berkembang dengan baik sebagai media pembelajaran yang menarik dan efektif bagi dunia pendidikan. Pengembangan diri pada setiap pendidik maupun peserta didik dalam kemajuan teknologi harus tetap diupgrade agar mampu mengikuti perkembangan zaman melalui teknologi yang selalu berkembang.

\section{DAFTAR RUJUKAN}

Aprilia Dewi Astuti, D. P. (2020). Efektivitas Penggunaan Media Belajar Dengan Sistem Daring Ditengah Pandemi Covid-19. Malang: Fakultas Ilmu Pendidikan Universitas Negeri Malang.

Argubi, A. H. 2020. Transformasi Pendidikan Di Tengah Pandemi Covid-19 dan Revolusi Industri 4.0. (Online). Diakses pada tanggal 29 Oktober 2020 melalui https://kahaba.net/opini/76985 transformasi-pendidikan-ditengah-pandemi-Covid-19dan-revolusi-industri-4-0.html,

Astini, N. K. (2020). Tantangan dan Peluang Pemanfaatan Teknologi Informasi dalam Pembelajaran Online Masa Covid-19. Jurnal Ilmu Pendidikan, 3(2), 241-255.

Briliannur Dwi C, dkk. (2020). Analisis Pembelajaran Online di Masa Pandemi Covid-19, Jurnal Pendidikan Guru Sekolah Dasar, 2(1).

Ceraolo C, Giorgi FM. (2020). Genomic variance of the 2019-n CoV coronavirus. Journal Med Virol, 9(2), 5228.

Dewi, W. A. (2020). Dampak Covid19 Terhadap implementasi Pembelajaran Daring di 
Sekolah Dasar. Jurnal Ilmu Pendidikan, 2(1), 55-61.

Diah Handayani, dkk. (2020). Penyakit Virus Corona 2019. Jurnal Respirologi Indonesia, 40(2).

Friendha Yuanta. (2019). Pengembangan Media Video pembelajaran Ilmu Pengetahuan Sosial pada Siswa Sekolah Dasar. Trapsila: Jurnal Pendidikan Dasar, 91-100.

Hanum, N. S. (2013). Keefektifan Elearning Sebagai Media Pembelajaran. Jurnal Pendidikan Vokasi, 92.

Hasanah, dkk. 2020. Analisis Aktivitas Belajar Daring Mahasiswa Pada Pandemi COVID-19. Jurnal Pendidikan, 1(1).

Islabiah, F. (2020). Pedoman Pencegahan dan Pengendalian Coronavirus Disease (Covid-19). Jakarta: Kementrian Kesehatan.

Islami, W. N. (2020). Konsep Perkuliahan Daring Google Classroom dalam Meningkatkan Interaksi Akademik di Tengah Pandemi Korona. Fikroh: Jurnal Pemikiran dan Pendidikan Islam, 112.

Munir. (2009). Pembelajaran Jarak jauh berbasis teknologi Informasi dan Komunikasi. Bandung: Alfabeta.
Korsman, S.N.J., VAN Zyl, G.U., Nutt, L., Andersson, M.I., Presier, W. (2012). Chins: Churchill Livingston Elsevier. Viroloy.

Oktafia Ika Handarini \& Siti Sri Wulandari. (2020). Pembelajaran Daring Sebagai Upaya Study From Home (SFH) Selama Pandemi Covid 19. Jurnal Pendidikan Administrasi Perkantoran (JPAP), 8(3).

Roida Pakpahan, Y. F. (2020). Analisa pemanfaatan Teknologi Informasi Dalam Pembelajaran Jarak Jauh di Tengah Pandemi Virus Covid19. Journal of Information System, Applied, Management, Accounting and Research, 3233.

Sugiono. (2012). Metode Penelitian Kuantitatif Kualitatif dan $R \& D$. Alfabeta.

Suartama, I Kadek. (2014). E Learning Konsep dan Aplikasinya. Singaraja: Ganesha University of Education.

Yuliana. (2020). Coronavirus dieases (Covid-19): Sebuah Tinjauan Literatur. Jurnal Wellness And Healty Magazine, 2(1).

Yaumi, Muhammad. (2018). Media dan Teknologi Pembelajaran. Jakarta: Prenadamedia Group. 